\title{
Eksistensi Kearifan Lokal Dalam Pendidikan Di Sulawesi Selatan
}

\author{
Ahmad Muzawir Saleh \\ Universitas Islam Negeri Alauddin Makassar \\ Ahmadmuzawirs71@gmail.com \\ Ismail Suardi Wekke \\ Institut Agama Islam Negeri (IAIN) Sorong \\ Email: iswekke@gmail.com
}

\begin{abstract}
Abstrak
Sulawesi Selatan sebagai salah satu daerah yang terletak di timur Indonesia dengan berbagai suku dan budaya juga merupakan daerah dengan kearifan lokal yang beraneka ragam. Kearifan lokal sebagai bentuk warisan peradaban yang turun-temurun haruslah tetap dijaga dan dilestarikan. Salah satu tempat yang dapat dipergunakan untuk menjaga eksistensi kearifan lokal adalah dalam pendidikan yang merupakan tempat untuk mendidik manusia menjadi lebih baik. Artikel ini di tulis menggunakan metode kualitatif untuk melihat jenis-jenis kearifan lokal yang ada dalam pendidikan di Sulawesi Selatan serta manfaatnya dalam kehidupan, sehingga dengan identifikasi tersebut maka kearifan-kearifan lokal tersebut dapat terjaga dan dilestarikan dengan baik.
\end{abstract}

\section{Kata Kunci: Kearifan Lokal, Sulawesi Selatan.}

\section{Pendahuluan}

Indonesia sebagai salah satu Negara dengan penduduk yang beragam dan majemuk, terdapat berbagai jenis suku, etnis yang membentuk berbagai macam kebudayaan yang beragam. Bentuk-bentuk kebudayaan itu meliputi kesenian-kesenian rakyat, upacara keadatan, system pengetahuan tradisional, bahasa, permainan rakyat, makanan dan minuman tradisional, arsitektur dan cerita rakyat yang kesemuanya itu merupakan kekayaan sosial yang dimiliki bangsa Indonesia. [1]

Kekayaan budaya tersebutlah yang kemudian menjadi sebuah nilai kerifan lokal bangsa yang harus dilestarikan. Selain itu, nilai-nilai yang terkandung didalamnya merupakan kearifankearifan dalam kehidupan masyarakat yang dapat digunakan sebagai pedoman dalam menjalani aktivitas maupun dalam pembentukan karakter manusia. Hal tersebut karena kearifan lokal merupakan pengetahuan yang mewujud pada perilaku sebagai hasil dari adaptasi terhadap lingkungan yang mempunyai implikasi positif terhadap kelestarian lingkungan. [2] juga merupakan pandangan hidup, ilmu pengetahuan, dan berbagai strategi kehidupan yang berwujud aktivitas, dilakukan oleh masyarakat setempat untuk menjawab berbagai masalah dalam pemenuhan kebutuhan [3] 
Salah satu provinsi yang memiliki bagitu banyak warisan kearifan lokal adalah sulawei selatan. Kepulauan yang terletak di wilayah timur Indonesia ini sarat akan kebudayaan dan tradisi yang telah di wariskan beratus-ratus tahun lalu. Sebagai salah satu wilayah yang memiliki empat suku besar yaitu Bugis, Makassar, Toraja, dan Mandar maka tentunya memiliki begitu beraneka ragam kearifan lokal sebagai perwujudan dari arus peradaban masyarakatnya. Keanekaragaman budaya daerah Sulawesi Selatan, antara lain berupa peninggalan sejarah, tardisi, dan adat-istiadat.[4]

Banyaknya kearifan lokal tersebut tentunya menjadi tanggung jawab tersendiri bagi manusianya untuk terus mempertahankan eksistensinya, sehingga tetap hadir sebagai salah satu pedoman untuk kehidupan. Warisan budaya yang turun-temurun tersebut tidak kesemuanya pun merupakan hal yang sesuai dengan kondisi zaman, sehingga diperlukan filter dengan tidak mengesampingkan keberadaan dan pelestarian kearifan local itu sendiri. Sehingga untuk menjawab hal tersebut maka diperlukan pendidikan sebagai tempat untuk menyesuaikan nilainilai kearifan lokal serta tetap menunjukkan eksistensinya dalam kehidupan.

Pendidikan yang menerapkan kearifan lokal dalam system pembelajaran sehari-hari biasa pula disebut sebagai etnopedagogy. Yaitu praktik pendidikan dimana pengetahuan dihasilkan, disimpan, diterapkan dan diwariskan melalui sarana kearifan lokal di sebuah daerah.[5] penelitian ini terasa penting agar dapat mendeteksi kearifan lokal yang dapat diterapkan atau yang masih bereksistensi di dunia pendidikan sampai saat ini. sehingga, kearifan lokal tersebut dapat terus di jaga dan dilestarikan agar tetap menjadi pedoman dan penunjang dalam mengarungi kehidupan sehari-hari terutama untuk peserta didik.

\section{Metode}

Penelitian dengan menggunakan desin kualitatif untuk mendeskripsikan hasil penelitian di berbagai literature ilmiah berupa buku maupun jurnal untuk melihat kearifan lokal yang terdapat dalam pendidikan di Indonesia.

\section{Hasil dan Pembahasan}

Kearifan lokal sering di peristilahkan dalam bahasa inggris sebagai Local Wisdom (Kebijakan Setempat) ataupun genius wisdom (kecerdasan setempat) [6] yang berarti usaha manusia yang menggunakan akal budinya untuk bertindak dan bersikap terhadap sesuatu, objek, atau peristiwa yang terjadi dalam ruang tertentu [7].

Berbicara kearifan lokal, maka akan terkait dengan sikap, pengetahuan dan kebiasaan yang diperlakukan dalam suatu daerah tertentu, yang dapat berupa tulisan, perkataan, maupun dalam bentuk perbuatan. Hasil studi kualitatif dari artikel ini menemukan beberapa kearifan lokal di Sulawesi selatan yang harus tetap perlu bereksistensi di dunia pendidikan sebagai salah satu sarana dalam pengembangan ilmu pengetahuan maupun sebagai penunjang dalam tata karma berperilaku sebagai salah satu pedoman akal budi peserta didik dalam kehidupan sehari-hari.

\section{Pappaseng (Petuah)}


Petuah atau yang dalam bahasa bugis disebut sebagai pappaseng adalah naskah yang berisi wasiat yang sarat akan sebagai pencerminan cara hidup dan warisan kebudayaan serta corak pikir manusia pada waktu itu. Pappaseng ini pada umumnya dilontarkan oleh seroang bangsawan, ataupun raja yang berkuasa pada saat itu. Ada pula yang berasal dari orang-orang cerdik, guru, maupun orang tua kepada anak-anaknya yang berisi tentang norma-norma kesusilaan. [8]

Dalam dunia pendidikan, pappaseng ini dapat dijadikan sebagai salah satu pedoman dalam penanaman nilai-nilai moral dan karakter dalam diri peserta didik. Pasalnya, terdapat berbagai nilai yang terkandung dalam pappaseng tersebut yang dapat berupa nilai religious, nilai kejujuran, nilai tanggung jawab, nilai disiplin, nilai kerja keras, nilai mandiri, nilai peduli sosial, dan nilai peduli lingkungan. [9]

Keberadaan pappaseng dalam dunia pendidikan yang ditanamkan kepada peserta didik akan menghasilkan manusia yang memiliki keteguhan hati, pandangan serta perilaku yang senantiasa terjaga. Hasil penelitian menunjukkan bahwa pappaseng sebagai pedoman hidup masih dipertahankan karena pengaruh positif yang terkandung menjadi perekat individu yang dijadikan pandangan hidup. [10] semisal pappaseng yang berbunyi Têllui riala sappo: tauq-e ri dêwata; siriq-ê ri watakkaletaq; siriq-ê ri padatta tau [11] yang berarti tiga diambil pagar: takut kepada Dewata (Allah), Malu pada diri sendiri, Malu kepada sesama manusia. Hal tersebut berarti bahwa ada 3 hal yang ketika dipegang erat sebagai pengangan atau penjaga dalam bertingkah laku maka akan terjaga kehidupannya di dunia.

\section{Cerita Rakyat}

Cerita rakyat merupakan cerita yang berasal dari masyarakat dan berkembang dalam masyarakat secara turun menurun dan disampaikan secara lisan. [12] cerita rakyat di setap daerah memiliki keunikan masing-masing yang mengandung nilai budaya maupun sejarah kehidupan dari daerah cerita tersebut berasal. Cerita rakyat bukan hanya bisa digunakan sebagai bahan hiburan semata tapi juga sebagai sarana pendidikan karena mengandung pesan-pesan moral maupun tuntunan-tuntunan dan pesan-pesan kehidupan.

Beberapa cerita rakyat yang dapat dijumpai di Sulawesi Selatan adalah putri tandampalik, daeng sinoraja, nenek pakande, ambo upe dan burung beo, cerita la upe dan raja ikan, I laurang manusia udang, kisah sawerigading, Lamaddukelleng, pung darek-darek na pung kura-kura[13]. Cerita-cerita rakyat tersebut mengandung berbagai macam pesan serta petuah-petuah untuk kehidupan dengan cerita yang melukiskan cerita protagonist dan antagonis yang dapat di tarik sebagai cerminan dalam bertingkah laku dalam kehidupan.

\section{Siri' na Pacce' (Malu dan Solidaritas)}

Siri' yang secara harfiah berarti malu, sedangkan secara makna merupakan suatu sistem nilai sosial, budaya dan kepribadian yang merupakan pranata pertahanan harga diri dan martabat manusia sebagai individu dan anggota masyarakat.[14] sedangkan pace secara harfiah diartikan sebagai perasaan pedih, pedis atau menyayat hati. Secara maknawi dapat diartikan sebagai 
perasaan menyayat hati, pilu bagaikan tersayat sembilu apabila sesama warga masyarakat atau keluarga atau sahabat ditimpa kemalangan (musibah) [15] sehingga dapatlah ia menjadi sebuah alat dalam mewujudkan sifat solidaritas, rasa kemanusiaan, memberi motivasi walaupun dalam keadaan yang berbahaya sekalipun [16]

Falsafah siri' na pacce' inilah yang harus terus ditanamkan dalam diri peserta didik, sebagai sebuah pemaknaan yang mendalam dari falsafah bugis Makassar yang mampu menciptakan orang-orang yang memiliki rasa malu yang kuat serta rasa solidaritas dan belas kasih yang dijunjung tinggi.

Nilai-nilai luhur dalam siri na pace merupakan gambaran kecil dari nilai-nilai budaya yang berakar pada system, tekad, dan prinsip yang esensial. [17] pada hakekatnya, falsafah tersebut merupakan bentuk dari kekayaan pola pikir yang dapat membentuk kekokohan martabat dan harkat dari bangsa ini, sehingga sudah sepatutnya jika pendidikan menjadi patron dalam penanaman nilai-nilai ini.

Peserta didik dengan mental dan pola pikir yang sejalan dengan siri na pacce akan menjadi generasi-generasi yang mampu bersaingdengan sportif dan juga berkompetisi tanpa kehilangan rasa simpati dan empati. Sehingga lahirlah generasi-generasi emas yang dapat menjadi tonggak pembaharuan serta pelanjut estafet kepemimpinan bangsa di masa depan.

\section{Budaya Tabe' (Permisi)}

Budaya tabe atau permisi merupakan salah satu bentuk ucapan yang di lontarkan kepada seseorang sebagai bentuk penghjormatan pada orang tersebut. Secara umum tabe' ini dalam konteks bugis dimaknai sebagai tanda permisi untuk melintas dihadapan orang lain dengan cara menundukkan kepala seraya mengucapkan "tabe puang/karaeng/andi/daeng". Dapat pula sebagai bentuk penghormatan ketika hendak menghadap kepada seseorang yang lebih tua ataupun orang yang memiliki gelar kebangsawanan. Serta juga digunakan ketika mengambil atau meletakkan sesuatu di hadapan orang lain.

Dalam pendidikan di Sulawesi selatan, budaya tabe ini harus menjadi halhal mendasar

yang diterapkan dalam kehidupan sehari-hari peserta didik, sehingga nilai-nilai kesopanan dan kesantunan melekat pada diri anak yang akan dibawa seterusnya, penanaman nilai tabe' ini dapat dilakukan dengan cara pembiasaan serta percontohan. Seorang guru harus menjadi patron dalam hal ini, dengan membiasakan diri mengucapkan kata tabe' maka peserta didik secara perlahan pula akan terbiasa dan dapat memaknainya dengan baik.

\section{Kesimpulan}

Kearifan lokal dalam pendidika harus tetap di berikan ruang untuk bereksistensi sebagai salah satu cara menjaga dan juga melestarikannya. Pesan-pesan moral dan panduan atau pedoman kehidupan yang terkandung didalamnya harus di pegang teguh dengan tetap menyelaraskan dengan perkembangan dunia saat ini sehingga proses keberlanjutan peradaban tetap terlaksana dengan koridor yang juga tetap menjunjung tinggi nilai-nilai kehidupan. 
Olehnya, pendidikan harus tetap menjadi episentrum pelestarian nilai-nilai budaya dan kearifan lokal dengan menanmkan sejak dini kepada para peserta didiknya.

\section{Referensi}

Hadianti, Dewi. Arisal. Marhani (2018). Nilai Kearifan Lokal Dalam Cerita Rakyat Dan Peranannya Dalam Membentuk Karakter Anak Didik. Seminar Nasional Administrasi Pendidikan dan Manajemen Pendidikan.

Salam, Rahayu. (2017) Kearifan Lokal Masyarakat Adat Dalam Pengelolaan Hutan di Pulau Wangi-wangi. Jurnal Walasuji Volume 8 No. 1. Balai Pelestarian Nilai Budaya Sulawesi Selatan.

Saihu. (2019). Pendidikan Karakter Berbasis Kearifan Lokal (Studi Di Jembrana Bali). Edukasi

Islami: Jurnal Pendidikan Islam, VOL: 08/NO: 01

Nurhaeda. (2018). Revitalisasi nilai-nilai 'Pappaseng' sebagai kearifan lokal masyarakat Bugis:

Konseling Eksistensial. Prosiding SNBK (Seminar Nasional Bimbingan dan Konseling) 2 (1), $295-313$

Chaedar Alwasilah. (2009). Etnopedagogi Landasan Praktik Pendidikan dan Pendidikan Guru. Bandung: PT Kiblat Buku Utama.

Irwan Abbas. .Pappaseng: Kearifan Lokal Manusia Bugis Yang Terlupakan, Vol.... no.....hal. 276

Koestoro, dkk. (2010). Kearifan Lokal dalam Arkeologi Seri Warisan Budaya Sumatera Bagian Utara No. 0510. Medan: Balai Arkeologi. Hal. 122

Saleh, Nuralam. (2006), "Pappasang Turiolo (Revitalisasi Nilai-Nilai Budaya dalam Kehidupan Orang Makassar". Jurnal Walasuji Vol I, No. 1. Hal. 105

Rasak, A., Nasrum., \& Syukur, H. (2019). The Values Of Ancestor's Messages (Pappaseng) In Buginese Tradition (Case Study On Bone Regency Students In UIN Alauddin Makassar). Elite Journal. 6(1). Hal. 95

Gani, Ambo, dkk. (1990). Wasiat-Wasiat dalam Lontarak Bugis. Jakarta: Departemen Pendidikan dan Kebudayaan. Hal. 52

Prusdianto, Hamrin, Faisal. (2019). Perancangan Perangkat Pembelajaran Drama Radio/ Televisi Berbasis Cerita Rakyat Sulawesi Selatan. Jurnal Imajinasi, Vol 3(2). Hal. 2

Nurhadifah Amaliyah, Isnaeni Wahab. (.....).Edukasi Guru Sd Dalam Penulisan Buku Cerita Berbasis Budaya Bugis Makassar. Jurnal...., Vol...(..). Hal. 59

Darwis, Rizal dan Asna Usman Dilo. (2012). Implikasi Falsafah Siri’ Na Pacce Pada Masyarakat Suku Makassar Di Kabupaten Gowa. Jurnal el Harakah, Vol. 14 (2). Hal. 190

Moein M.G., Andi. 1990. Menggali Nilai-Nilai Budaya Bugis-Makassar dan Sirik na Pacce. Ujung Pandang: Mapress. Hal. 33

Limpo, Syahrul Yasin. 1995. Profil Sejarah, Budaya dan Pariwisata Gowa. (Cet. I). Ujung Pandang: Intisari. 91

Hardianto Rahman. (2014). Konsep Budaya Sirik Na Pacce Dan Pendidikan Karakter (Studi Model Pembelajaran Integratif). Al-Qalam , Vol. 6 (2), Hal. 34 
